\title{
Ennustemenetelmä porkkananmustamädän aiheuttamiin varastotuhoihin
}

\author{
Tuija-Liina Laamanen ${ }^{1)}$, Terhi Suojala-Ahlfors ${ }^{1)}$, Päivi Parikka ${ }^{2)}$ ja Marja Lehto ${ }^{3)}$ \\ ${ }^{1)}$ MTT kasvintuotannon tutkimus, Toivonlinnantie 518, 21500 Piikkiö, \\ tuija-liina.laamanen@helsinki.fi, terhi.suojala-ahlfors@mtt.fi \\ ${ }^{2)}$ MTT kasvintuotannon tutkimus, 31600 Jokioinen, paivi.parikka@mtt.fi \\ ${ }^{3)}$ MTT kotieläintuotannon tutkimus, Vakolantie 55, 03400 Vihti, marja.lehto@mtt.fi
}

Porkkananmustamätä (Mycocentrospora acerina) on yksi pahimpia porkkanan varastotauteja. Se pilaa vuosittain kymmeniä prosentteja varastoitavasta porkkanasadosta. Varastotuhojen laajuus vaihtelee huomattavasti vuosittain ja tuotantoerittäin. Porkkananmustamädän vähentäminen on vaikeaa, sillä tauti säilyy maassa useita vuosia kätköitiöiden turvin.

MTT:n ja Helsingin yliopiston hankkeessa "Tuorevihannesten hygienia: raaka-aine, tuote, vesi ja jätteet" sekä MTT:n ja Yara Suomen hankkeessa "Porkkanan tuotanto 2010-luvulle: parempaa laatua, vähemmän jätettä" kehitettiin ennustemenetelmää porkkananmustamädän aiheuttaman tautipaineen arvioimiseksi maanäytteistä. Menetelmä on ideoitu hankkeessa "Porkkanan kuluttajalaadun parantaminen" (2005-2008). Tavoitteena on, että ennustemenetelmän avulla viljelijät pystyisivät huomioimaan entistä paremmin porkkananmustamädän aiheuttamaa tuotantoriskiä viljelyja markkinointisuunnitelmissaan ja siten vähentämään sienitaudista johtuvia sadon menetyksiä. Tällöin myös porkkanantuotannon kannattavuus paranisi.

Porkkananmustamätätestin testaamista ja kehittämistä varten kerättiin maanäytteitä 18 peltolohkolta (yht. 53 näytettä) vuonna 2009 ja 20 lohkolta (yht. 64 näytettä) vuonna 2010. Kaikki maanäytteet testattiin laittamalla pakasterasioihin multanäytteen pällle syöttikasvina toimivia porkkanakiekkoja ja kasvattamalla sieni mullasta porkkanakiekkoihin kuuden viikon aikana pimeässä $+15{ }^{\circ} \mathrm{C}$ :ssa. Testin toimivuutta arvioitiin vertaamalla maanäytteistä porkkanakiekkoihin kasvaneen porkkananmustamädän määrää samoilta peltolohkoilta kerättyjen ja varastoitujen satonäytteiden porkkananmustamädän määrään. Lisäksi selvitettiin eri lajikkeiden soveltuvuutta syöttikasviksi sekä testausajankohdan vaikutusta testin tuloksiin.

Vuoden 2009 aineiston mukaan porkkananmustamätätesti ennakoi tilastollisesti merkitsevällä tarkkuudella pitkäaikaiseen varastointiin tarkoitettujen porkkanalajikkeiden säilyvyyttä. Vuoden 2010 testin tulokset eivät vastanneet tilastollisesti merkitsevästi sadon varastointikokeen tuloksia, sillä tuloksissa esiintyi runsasta vaihtelua, mikä selittynee kasvukauden 2010 poikkeuksellisilla sääoloilla. Hankkeen tulokset osoittavat testimenetelmän ennustavan suuntaa antavasti porkkananmustamädän aiheuttamaa satohävikkiä normaaleissa kasvuolosuhteissa. Luotettavien tulosten saamiseksi testi tulee kuitenkin tehdä riittävän suurella näytemäärällä.

Asiasanat: porkkananmustamätä, Mycocentrospora acerina, ennustemenetelmä, satotappio, varastointi, säilyvyys 


\title{
Johdanto
}

Porkkanantuotanto on Suomessa ammattimaista ja erikoistunutta. Kuitenkin vuosittain varastotaudit aiheuttavat suuria satotappioita. Satotappiot aiheuttavat tulon menetyksiä porkkanantuottajille ja muille tuotanto- ja kauppaketjun osapuolille. Lisäksi pilaantuneen sadon hävittämisestä aiheutuu kustannuksia. Varastotappiot ovat huomattava rasite suomalaiselle porkkanatuotannolle talvikauden aikaisen pitkän varastointikauden takia. Satoa varastoidaan jopa puoli vuotta, jolloin porkkanoiden vastustuskyky heikkenee ja varastotaudit saavat mahdollisuuden pilata satoa. Varastotappioiden voimakkuus vaihtelee vuosittain ja tuotantoerittäin. MTT:1lä on verrattu eri peltolohkoilla tuotettujen porkkanaerien säilyvyyttä. Vuonna 2005 tautien pilaamien porkkanoiden osuus vaihteli maaliskuussa 2-100\% ja vuonna 20060 - $85 \%$ (Vanhala 2008).

Suomessa varastoinnin aikaiset satotappiot aiheutuvat pääosin varastotaudeista. Yleisimpiä porkkanasatoja pilaavia tauteja ovat porkkananmustamätä, harmaahome ja pahkahome (Årsvoll 1969). Taudit tulevat porkkanasadon mukana pellolta varastoon. Taudinaiheuttajat ovat saprofyyttejä sieniä, jotka pilaavat satoa muodostamalla porkkanoihin mätälaikkuja. Satoa pilaavien sienien kasvua pyritään hillitsemään säätämällä varastojen lämpötilaa ja ilmankosteutta. Porkkanavarastoissa lämpötila pidetään lähellä nollaa ja suhteellinen ilmankosteus lähellä sataa, jolloin porkkanoiden elintoiminnot ja fysiologinen vanheneminen hidastuu. Alhainen lämpötila hidastaa myös sienten kasvua.

Porkkananmustamätä on vaikeasti kontrolloitava tauti. Taudinaiheuttaja on maalevintäinen sieni. Viljelykierto ei ole tehokas menetelmä tautipaineen pienentämiseksi, sillä sienen kestomuodot, kätköitiöt, säilyvät maassa elinkykyisinä useita vuosia (Hermansen ym. 1997). Porkkananmustamädän isäntäkasveja ovat porkkanan lisäksi useat rikkakasvit, kuten esimerkiksi yleisesti esiintyvä peltoorvokki (Viola arvensis) (Hermansen 1992b). Peltolohkon tautipaineen suuruutta ei voida arvioida yksinomaan viljelyhistorian perusteella rikkakasvien toimiessa isäntäkasveina. Porkkananmustamädän oireita voi havaita joissain tapauksissa jo porkkanan lehdissä kasvukaudella (Årsvoll 1969). Yleensä tauti ilmenee kuitenkin vasta varastokaudella. Tyypillisesti taudin oireet tulevat esiin kevättalvella, sillä M. acerina on hidaskasvuinen sieni.

Varastotappioiden voimakkuus ja tuotantoerien välillä esiintyvän vaihtelun suuruus osoittavat, että nykyiset menetelmät eivät ole riittäviä ja porkkanantuotantoon kaivataan uusia menetelmiä. "Laatuvihannesten hyvät viljelymenetelmät"-tutkimuksen loppuraportissa Suojala \& Pessala (1998) toteavat tautien esiintymisen vaikuttavan ratkaisevasti porkkanan varastoinnin onnistumiseen ja että on tarvetta kehittää ennustemenetelmä tautipaineen arvioimiseksi. Tässä tutkimuksessa testataan ja kehitetään Päivi Parikan hankkeessa "Porkkanan kuluttajalaadun parantaminen" (Vanhala 2008) ideoimaa ennustemenetelmää porkkananmustamädän tautipaineen ennustamiseksi maanäytteistä. Tutkimuksen tavoitteena on testata ja arvioida testimenetelmän toimivuutta suurilla aineistoilla ja tarkentaa testimenetelmää.

Tämä tutkimus kuuluu osaksi hankkeita "Tuorevihannesten hygienia: raaka-aine, tuote, vesi ja jätteet - TUOVI" sekä "Porkkanan tuotanto 2010-luvulle: parempaa laatua, vähemmän jätettä". TUOVI hankkeessa pyritään kehittämään koko tuotantoketjua pellolta prosessoituihin tuotteisiin asti ja Porkkana 2010 -hankkeessa keskitytään alkutuotannon kehittämiseen. Ennustemenetelmä porkkananmustamädän tautipaineen ennustamiseksi helpottaisi viljely- ja markkinointisuunnitelmien tekemistä, jolloin markkinoitavan porkkanan laatu paranisi. Tällöin lajitteluhävikki vähenisi sekä tuottajilla että elintarviketeollisuudessa. Samalla myös lajittelujätteen hävittämisestä aiheutuvat kulut ja ympäristöhaitat vähenisivät.

\begin{abstract}
Aineisto ja menetelmät
Koeaineisto kerättiin kasvukausina 2009 ja 2010 Forssan ja Laitilan seudun pelloilta, joissa koevuonna viljeltiin porkkanaa. Koepeltoja ei valittu maalajin, viljelyhistorian tai muun vastaavan ominaisuuden perusteella, joten aineisto edustaa kattavasti porkkanan tuotantoalueiden olosuhteita. Porkkananmustamätätestiä varten kerättiin koepelloilta maanäytteet keväällä ennen porkkanan taimettumista ja uudestaan samoilta alueilta syksyllä sadonkorjuun aikaan. Kasvukaudella 2009 näytteitä kerättiin 18 peltolohkolta. Jokainen peltolohko jaettiin 2 - 4 osaan, jolloin
\end{abstract}


kokonaisnäytemäärä oli 53 näytettä. Vuonna 2010 peltolohkoja oli 20. Peltolohkot jaettiin 3 - 4 osaan, jolloin kokonaisnäytemäärä oli 64 näytettä. Maanäytteet kerättiin maanäytekairalla muokkauskerroksesta ja koostettiin noin 20 osanäytteestä.

Porkkananmustamätätesti tehtiin asettamalla pakasterasian (V=0,5 l) pohjalle noin $1 \mathrm{~cm}: n$ paksuinen kerros testattavaa maata. Tarvittaessa maanäytettä kostutettiin. Maanäytteen päälle asetettiin pestyistä ja kuorituista porkkanoista leikattuja noin 3 - $4 \mathrm{~mm}$ paksuja porkkanakiekkoja. Jokaiseen testirasiaan asetettiin kuusi porkkanakiekkoa. Testirasiat suljettiin ja varastoitiin kuuden viikon ajan pimeässä $+15{ }^{\circ} \mathrm{C}$ :ssa. Kuuden viikon aikana porkkananmustamätäsieni ehti kasvaa maanäytteistä syöttikasveina toimiviin porkkanakiekkoihin aiheuttaen niihin mätälaikkuja. Maanäytteiden kosteus tarkistettiin pari kertaa varastoinnin aikana. Tarvittaessa lisättiin vettä ja samalla poistettiin itäneet rikkaruohot. Keväällä kerätyille maanäytteille porkkanamustamätätesti tehtiin kesällä heti näytteiden keräämisen jälkeen. Osa keväällä kerätyistä maanäytteistä säilytettiin pakastamalla $\left(-20^{\circ} \mathrm{C}\right)$ syksyyn uusintatestiä varten. Syksyllä porkkananmustamätätesti tehtiin syksyn maanäytteiden keräämisen jälkeen samanaikaisesti syksyllä kerätyille maanäytteille ja keväällä kerätyille maanäytteille. Vuonna 2009 jokaisesta maanäytteestä tehtiin kaksi rinnakkaista testirasiaa. Vuonna 2010 rinnakkaisia testirasioita tehtiin jokaisesta maanäytteestä kolme kappaletta. Kesän 2009 testissä syöttikasvina käytettiin porkkanalajiketta 'Fontana', syksyn 2009 testissä lajiketta 'Nerac', kesän 2010 testissä lajiketta 'Natalja' ja syksyn 2010 testissä lajiketta 'Nanda'. Kuuden viikon varastoinnin jälkeen havainnoitiin silmämääräisesti porkkanakiekkoihin kasvaneet porkkananmustamädän aiheuttamat mätälaikut. Porkkananmustamädän vioittamat porkkanakiekot ja porkkananmustamädän määrä jokaisessa porkkanakiekossa kirjattiin muistiin. Silmämääräisen taudintunnistuksen varmistamiseksi osasta mätälaikkuja otettiin näytteet. Näytteet kasvatettiin PDAalustoilla ja kasvatuksen jälkeen taudinaiheuttaja tunnistettiin mikroskopoimalla.

Porkkananmustamätätestin toimivuuden arvioimiseksi selvitimme koepelloilla kasvatetussa porkkanasadossa esiintyvän todellisen porkkananmustamädän määrän keräämällä verrannenäytteet (satonäytteet) ja tekemällä sadon varastointikokeen. Satonäytteet kerättiin samoilta alueilta kuin mistä maanäytteet oli kerätty. Jokaiselta koealueelta kerättiin ja listittiin käsin noin $8 \mathrm{~kg}$ porkkanoita. Satonäytteet vietiin MTT:n koevarastoon Piikkiöön sadonkorjuupäivänä (vuoden 2009 kokeessa 16.9. - 1.10. ja vuoden 2010 kokeessa 9.9. - 5.10). Varastossa porkkanat olivat polypropeeni-säkeissä. Koevaraston lämpötila oli asetettu $0,5{ }^{\circ} \mathrm{C}$ :een ja ilmankosteus yli $97 \%$ :iin. Sadon varastointikoe purettiin helmikuussa (vuoden 2009 sato 15. - 16.2.2010 ja vuoden 2010 sato 21. - 22.2.2011). Porkkanat pestiin ja lajiteltiin porkkanamustamädän ja muiden varastotautien vioittamiin, sekä terveisiin. Porkkananmustamädän vioittamat porkkanat lajiteltiin lisäksi viiteen luokkaan vioitusten voimakkuuden mukaan. Lajitelluista porkkanoista laskettiin kappalemäärät.

Vuonna 2010 tehtiin porkkananmustamätätestin lajikekoe. Tarkoituksena oli selvittää erityyppisten lajikkeiden soveltuminen käytettäväksi syksyllä syöttiporkkanana porkkananmustamätätestissä. Lajikekokeessa mukana olivat lajikkeet 'Napoli', 'Nanda', 'Namdal' ja 'Nerac'. Lajikekoetta varten kerättiin syksyllä maanäytteitä kolmelta eri porkkanapellolta. Jokaiselta peltolohkolta kerättiin kaksi erillistä maanäytettä kymmenen metrin etäisyydeltä toisistaan noin 0,25 $\mathrm{m}^{2}: n$ alalta. Lisäksi oli kontrollimaanäytteenä autoklaavissa desinfioitu hiekka. Jokaisella porkkanalajikkeella tehtiin porkkananmustamätätesti jokaisella seitsemällä maanäytteellä. Testi tehtiin neljänä kerranteena.

Porkkananmustamätätestin tulokset laskettiin keskiarvona havainnoista. Laskennassa huomioitiin jokaisesta porkkanakiekosta onko porkkanakiekossa mustamätää ja lisäksi kuinka suuri osa porkkanakiekosta on porkkananmustamädän pilaama. Sadon varastointikokeessa laskettiin porkkananmustamädän pilaamien porkkanoiden osuus sadosta.

Porkkananmustamätätestin toimivuutta arvioitiin vertaamalla porkkananmustamätätestin ja sadon varastointikokeen tuloksia toisiinsa. Vertailu tehtiin hajontakuvilla ja lineaarisella regressiolla. Analysointivaiheessa aineistoa ryhmiteltiin sadon varastointikokeessa olleen porkkanalajikkeen ja nostoajankohdan mukaan. Porkkanamustamätätestin lajikekokeen tulokset analysoitiin laskemalla eri maanäytteiden keskiarvotulokset ja vertaamalla lajikkeita toisiinsa. 


\section{Tulokset ja tulosten tarkastelu}

Sadon varastointikokeessa varastotautien pilaamista porkkanoista suurin osa oli porkkanamustamädän pilaamia. Porkkananmustamätätestin tulokset vastasivat sadon varastointikokeen verrannenäytteiden tuloksia tilastollisesti merkitsevällä tarkkuudella $(\mathrm{P}=0,0315)$ vuonna 2009 pitkäaikaiseen varastointiin tarkoitetuilla lajikkeilla (Kuva 1.). Sadon nostoajankohdalla oli vaikutusta sadon säilyvyyteen. Viikolla 40 nostetuissa porkkanoissa oli huomattavasti vähemmän porkkananmustamätää kuin viikoilla 38 ja 39 nostetuissa porkkanoissa. Havainto vastaa aiempia tuloksia, joiden mukaan porkkanoiden säilyvyys paranee nostoajankohdan ollessa myöhäisempi (Suojala \& Pessala 1998). Myös porkkanalajikkeella oli vaikutusta sadon säilyvyyteen. Lyhytaikaisempaan varastointiin tarkoitetuissa lajikkeissa esiintyi runsaammin porkkananmustamätää. Lyhytaikaiseen varastointiin tarkoitetut lajikkeet jätettiin pois porkkananmustamätätestin tulosten tarkastelusta, sillä ne eivät olleet vertailukelpoisia pitkään varastointiin tarkoitettujen lajikkeiden tulosten kanssa. Toisaalta porkkananmustamätätestiä ei ole suunniteltukaan lyhytaikaisesti varastoitavien lajikkeiden tuotantoa varten, sillä porkkananmustamätä ei ole niin merkittävä ongelma lyhytaikaisesti varastoitavien lajikkeiden tuotannossa. Vuoden 2010 epätavalliset ja vaihtelevat sääolot loivat eri peltolohkoilla kasvaneille porkkanoille hyvin erilaiset kasvuolot, mikä näkyy tuloksissa huomattavana vaihteluna. Vuonna 2010 porkkananmustamätätestin ja sadon varastointikokeen tulokset eivät vastanneetkaan toisiaan tilastollisesti merkitsevällä tarkkuudella.

Porkkanamustamätätestin ja sadon varastointikokeen tulokset osoittavat että porkkananmustamätätesti pystyy ennustamaan suuntaa antavasti porkkananmustamädän esiintyvyyttä varastoidussa sadossa normaaleissa kasvuoloissa. Testi kertoo pellolla olevasta tautipaineesta. Tämän lisäksi sadon säilyvyyteen varastossa vaikuttavat monet tekijät, kuten kasvukauden aikaiset sääolot, nostoajankohta ja porkkanoiden kolhiintuminen noston yhteydessä, varastointiolosuhteet ja -aika sekä lajike.

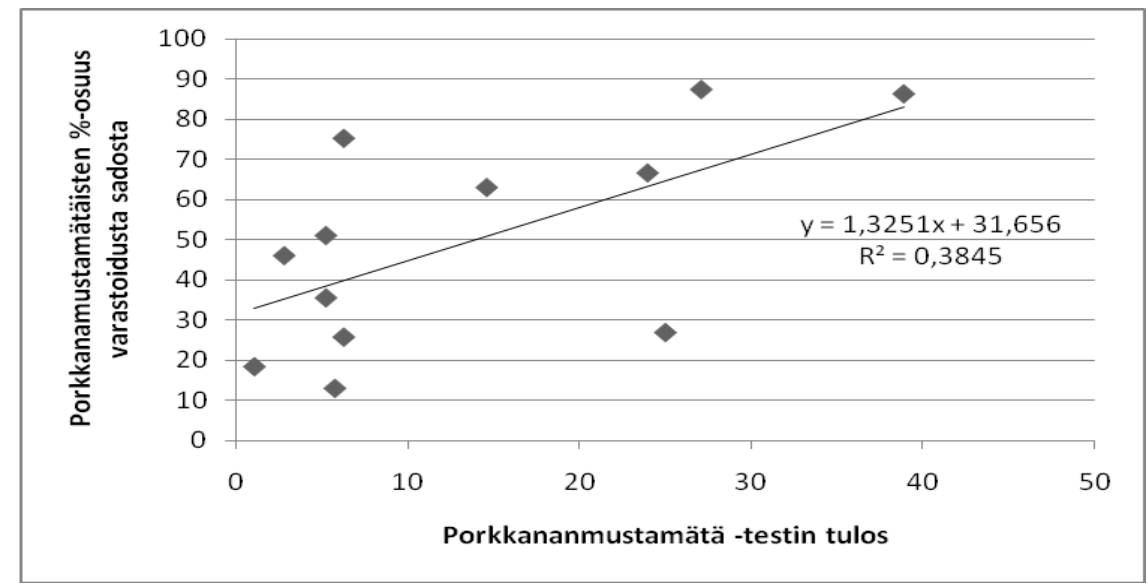

Kuva 1. Porkkananmustamätätestin (keskiarvo mädän määrästä porkkanakiekoissa) ja pitkään varastointiin tarkoitettujen lajikkeiden varastointikokeen tulokset 2009. Hajontakuvassa yksi piste on yhden pellon porkkananmustamätätestin ja varastointikokeen tulos.

Rinnakkaisten testirasioiden ja pellon eri osien välillä tuloksissa esiintyy vaihtelua. Vaihtelun perusteella voimme päätellä testin olevan melko herkkä testirasioiden välisille eroille. Rasioissa oleva kosteuden määrä vaihteli, vaikka rasioiden välisiä eroja pyrittiinkin tasoittamaan lisäämällä vettä kuivimpiin rasioihin. Liiallista kosteutta ei kuitenkaan pystynyt helposti poistamaan rasioista. Oletettavasti maanäytteiden kosteus vaikuttaa porkkananmustamädän aktiivisuuteen kasvaa maasta porkkananpaloihin. Eri testirasioihin jaetuissa maanäytteissä on saattanut olla eri määrä porkkananmustamätäsientä ja se voi aiheuttaa tuloksiin vaihtelua. Näin siitä huolimatta, että maanäytteistä pyrittiin tekemään mahdollisimman tasaisia koostamalla maanäytteet osanäytteistä ja sekoittamalla näytteet. Vaihtelua tuloksiin saattaa aiheuttaa myös syöttikasvina toimivien porkkanankiekkojen ominaisuudet. Osa porkkanakiekoista on voinut olla alttiimpia 
porkkananmustamädälle kuin toiset. Tosin rasioiden välisiä eroja pyrittiin tasoittamaan jakamalla kuhunkin rasiaan useasta eri porkkanasta leikattuja kiekkoja. Rasioiden välinen vaihtelu tuloksissa osoittaa, että rinnakkain tehtävien testirasioiden olosuhteet tulee pyrkiä pitämään mahdollisimman samanlaisina. Kokeessa käytetty porkkanakiekkojen määrä $(6 \mathrm{kpl})$ osoittautui vähäiseksi, yhden porkkanakiekon tuloksen vaikuttaessa lopputulokseen melko voimakkaasti.

Verrattaessa samasta maanäytteestä keväällä ja syksyllä tehtyjä porkkananmustamätätestejä sekä eri vuosina tehtyjä testejä havaitaan selviä eroja esiin tulevan porkkanamustamädän määrässä. Keväällä tehdyissä porkkanamustamätätesteissä tautia tulee näkyviin huomattavasti enemmän kuin syksyllä tehdyissä testeissä. Oletettavasti ero johtuu syöttikasvina toimivien porkkanakiekkojen alttiudesta porkkananmustamätäsienelle. Kevään testeissä käytettiin syöttikasvina yli talven varastoitua porkkanaa, jonka taudinvastustuskyky on oletettavasti heikompi verrattuna syksyllä syöttikasvina käytettyyn uuden sadon porkkanaan. Erot eri aikoina tehdyissä testeissä osoittavat, että tuloksia tarkasteltaessa eri aikoina tehtyjen testien tuloksia ei tule verrata toisiinsa, vaan testin tuloksia tulee tarkastella vertaamalla yhtä aikaa testattuja peltoja toisiinsa.

Porkkananmustamätätestin lajikekokeen tulosten mukaan lajikkeiden välillä ei ole huomattavia eroja. Kaikki testatut lajikkeet osoittivat maanäytteissä olevan porkkananmustamädän suunnilleen yhtä voimakkaasti syksyllä porkkanoiden ollessa uutta satoa (Kuva 2.). Oletettavasti erot lajikkeiden välillä tulisivat esiin myöhemmin talven aikana.

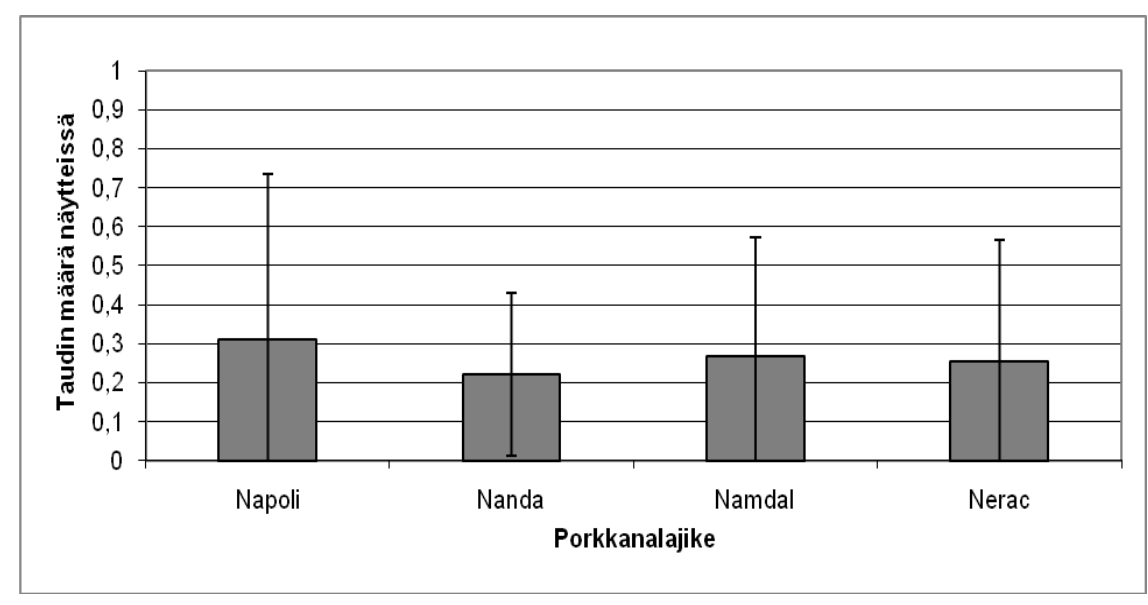

Kuva 2. Porkkanalajikkeiden osoittaman porkkananmustamädän määrä. Keskiarvo ja keskihajonta seitsemästä maanäytteestä, joista yksi kontrollimaanäyte.

\section{Johtopäätökset}

Porkkananmustamätätesti pystyy ennustamaan suuntaa antavasti sadon säilyvyyttä pitkään varastoitavilla lajikkeilla. Viljelijät voivat tehdä testiä yksinkertaisin välinein porkkanapelloistaan. Porkkananmustamätätestin tekemisessä on kiinnitettävä huomiota siihen, että kaikki halutut peltomaat testataan yhtä aikaa ja samalla tavalla, tulosten vertailukelpoisuuden varmistamiseksi. Eri aikoina tehtyjen testien tulokset eivät ole vertailukelpoisia. Tehtäessä testiä syksyllä syöttiporkkanaksi sopivat kaikki lajikkeet. Talvella tai keväällä testiä tehtäessä voidaan olettaa, että syöttiporkkanaksi soveltumattomat porkkanalajikkeet on jo syöty pois tai ne ovat pilaantuneet.

Porkkanamustamätätestin tuloksia hyödynnettäessä tulee muistaa, että sadon säilyvyyteen vaikuttaa tautipaineen lisäksi monet tekijät kasvukaudella, sadonnostossa ja varastoinnissa. Viljelijät voivat tehdä porkkananmustamätätestiä keväällä tai kesällä saadakseen tietoa nosto- ja markkinointiaikataulun tekemiseen. Syksyn ja talven aikana viljelijät voivat testata seuraavalle vuodelle varattuja peltolohkoja ja hyödyntää tuloksia viljelysuunnitelmien tekemisessä. Pitkäaikaisesti varastoitavan porkkanan tuotantoon on hyvä pyrkiä valitsemaan mahdollisimman vähäisen tautipaineen omaavia peltolohkoja. Korkean tautipaineen peltolohkot soveltuvat paremmin kesäporkkanan ja lyhytaikaisesti varastoitavan porkkanan tuotantoon. Välttämällä pitkään 
varastoitavien porkkanaerien viljelyä suuren tautipaineen omaavilla pelloilla, voidaan vähentää porkkananmustamädän aiheuttamia satotappioita.

\section{Kiitokset}

Tutkimuksen mahdollistivat rahoituksellaan Varsinais-Suomen ELY-keskus, Maiju ja Yrjö Rikalan Puutarhasäätiö sekä hankkeisiin osallistuneet viljelijät ja yritykset.

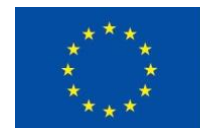

Euroopan maaseudun

kehittämisen maatalousrahasto:

Eurooppa investoi maaseutualueisiin

\section{Kirjallisuus}

Hermansen, A. 1992b. Weeds as hosts of Mycocentrospora acerina. Annals of Applied Biology 121: 679-686 Hermansen, A., Amundsen, T., Taksdal, G., Dragland, S., Synnevåg, G., Flønes, M. \& Sundheim, L. 1997. Mycocentrospora acerina in carrots; Effects of crop rotation on disease incidence. Annals of Applied Biology 131: 339-411

Suojala, T. \& Pessala, P. 1998. Viljelytoimien vaikutus avomaanvihannesten satoon ja varastokestävyyteen. Teoksessa: Terhi Suojala \& Raili Pessala (toim.) Tutkimusohjelman "Laatuvihannesten hyvät viljelymenetelmät" loppuraportti. Maatalouden tutkimuskeskuksen julkaisuja, sarja A 43: 77-84

Vanhala, P., Kallela, M., Pitkänen, T. \& Suojala-Ahlfors, T. 2008. Porkkanan varastokestävyys ja viljelytekijät. Teoksessa: Petri Vanhala (toim.) 2008. Porkkanan kuluttajalaadun parantaminen. Maa- ja elintarviketalous 128: 105-121. Elektroninen julkaisu: http://www.mtt.fi/met/pdf/met128.pdf

Årsvoll, K. 1969. Pathogens on carrots in Norway. Meldinger fra Norges landbrukshøgskole 48(2):52 